\title{
TheRice Straw Organizations in Japan :Preservation and Development Methods of Japanese Rice Straw Culture
}

\author{
Pandu Purwandaru ${ }^{1}$, FengTien $\mathrm{Wei}^{2}$ and Akira Ueda ${ }^{2}$ \\ ${ }^{1}$ Universitas Sebelas Maret, Surakarta, Indonesia \\ ${ }^{2}$ Chiba University, Chiba, Japan \\ ${ }^{1}$ pandupurwandaru@staff.uns.ac.id, ${ }^{2}$ twfeng@ms18.hinet.net \\ 2aued@faculty.chiba-u.jp
}

\begin{abstract}
Japan has been listed by FAO (Food and Agriculture Organization) as the top ten countries with the most rice producers in the world. In line with this achievement, Japan is known for its rice straw utilization culture or in Japanese called nihon no wara no bunka. In the modern era nowadays, Japanese rice straw culture, the same as another majority of traditional cultural problems, is gradually abandoned by the community. To tackle this situation, several people who have a concern in rice straw culture were initiating a rice straw community. In this research, there are data from three rice straw communities that have been collected such as Inagaki Wara no Kai, Warashibe, and Mingikai. These communities are working to preserve and develop the rice straw culture and have been successfully increasing the interest of both young and old generations inside the community to participate in the events. To sustainably run the activities there are several aspects to be considered by the rice straw communities in Japan, such as management, development, marketing and economic strategies.
\end{abstract}

Keywords: Rice straw culture, preservation, development, community, sustainability

\section{INTRODUCTION}

Japan has a long history of rice straw utilization culture. This culture is known as nihon no wara no bunka (日本の菜の文化) and existed since the era of Yayoi Period or $200 \mathrm{BC}$ [1]. In Japanese traditional farming communities, rice straw was utilized for their daily needs both in terms of utility and ritual items or in Japanese called as hare toke no hi (ハレの日とケの日) [2]. The diversity of this utilization culture was spread almost in all rice farming areas in Japan, and hundreds of rice straw artefact collection are exhibited in several museums in Japan, such as National Museum of Japanese History, in Chiba Prefecture, and Misato Town Museum of History and Folklore in Akita Prefecture. Inside these museums, the collections are separated between the utilization for festival and rituals, and daily needs such as rice straw sandals, farming tools, and other artefacts.

In the modern era, as the same problem faced by most of the traditional culture nowadays, rice straw culture is gradually abandoned by Japanese especially those who lived in rice 
farming communities. Therefore, rice straw is not optimally utilized anymore by the local community. As a solution to eliminating this material, most of rice straws are being burned such as happened in Saga Prefecture. Inside the soil, there are a lot of microorganisms and small insects that needed for the natural balance and fertility for rice plants. Burning activities in the rice field potentially bring negative impacts by reducing the number of living things that needed for plants' fertility. The pollution produced from these activities also brings health problems for the community who lived around the rice field areas.

According to the traditional Japaneserice farming communities'perspective in the past, rice straw is the parent of rice straw. Therefore, it wasinappropriateif we assume rice straw as waste material. The culture of mottainai (もつたいない) and moushiwakenai (申し訳ない) in Japanese society also supporting the traditional community in avoiding rice straw to becoming a wasteful material and optimally utilizing it into meaningful objects. Mottainaiis the idea that "something should be left as is it even though it is useful and that it is a shame to waste it", and moushiwakenaiin this research context is "the word that expresses to apologize from the heart in response to using a resource provided by nature in a wasteful fashion" [3].Kiyoshi Miyazaki, the emeritus professor of Design Culture laboratory Chiba University, describing the shape from Japanese kanji of rice straw word, wara (葈)aswarawaki to onajikuraitakaikachi o motta kusa (木と同じくらい高いを持った草) or it translated as rice straw is a grass that has the same values with wood [4].This definition is a representation of the value of straw for the life of traditional Japanese society in the past.

\section{METHOD}

This research is aimed to understand the element of rice straw organization in Japan which supports the sustainability of the activities. To achieve this output, as the method there are three approaches used by researchers: field research, reference studies, and data analysis. Field research was conducted in three rice straw communities in Japan, Inagaki Wara no Kai in Inagaki Village, Warashibe in Yokohama City, and Mingikai, Kawasaki City. These communities were selected for this research based on the recommendation from the laboratory of Design Culture Chiba University which previously conducted research on rice straw culturein several places in Japan. In our activities, we were having a discussion with community members forcollecting data related to the history, organization structures, and strategies. The second method isreference studies that were conducted to collect data related to the history of rice straw culture and thebackground of rice straw utilization. After the data are collected, the last method is data processing and analyzing the organizations' structures, and strategy to create a sustainable rice straw community, which consists of economy, marketing, resource management, internal and external relations, sponsorship, development approach, and preservation approach.

\section{RESULT AND DISCUSSION}

Result and discussion will be divided into the background (history), organization strategy (management structure and development strategy), and the organizations' impacts.

\subsection{Rice Straw Organization History}

Each rice straw organization in this research has a different history at the beginning of its pioneering. The detail of history is described below: 


\subsubsection{Inagaki Wara no Kai}

This organization was initiated by Kimihide Nagase. He has an interest in rice straw culture inspired by Professor Kiyoshi Miyazaki's research of Japanese rice straw culture when he took studies at Chiba University. During his studies in Inagaki, he learned a lot of things related to rice straw craft. After he graduated he decided to move to this village from Osaka city, works as local government staff while initiating the rice straw organization.

In the beginning, Nagase was targeting children for rice straw workshop, creating simple craft which could be finished in 1 to 2 hours. On a process to start this organization, he explored rice straw artefacts both values and production methods for creating workshop alternatives, until Katsuuyuki Nozaki a high school teacher joined in 2004, they started to create rice straw organization named Inagaki Wara no Kai [5].

\subsubsection{Warashibe}

Warashibe was born in 2017, from the initiative of Masahiro Mizuno alumni of Design Culture laboratory and Mitsuzo Arakawa a master in rice straw craft maker. This community is created by the initiators' observation in the Kagura temple in Yokohama. Every year, there is a routine activity by the local community in creating shimenawa or special rope made by rice straw tied around or across an object or space to detonate its sanctity or purity. This routine activity inspired both of the founders to initiate aorganization that focusing on preserving rice straw artefacts not only shimenawa but also other artefacts [6].

\subsubsection{MinguSeisakuGijutsuHozonkai (Mingikai)}

The rapid development in the modern days has been producing advance technology and science which make life rich and varied. Despite the success of this advancement, the manufactures which produce numerous products as an implementation of technology and science, have brought negative impacts such as environmental and social problems. Through this background, a group named Mingikai, the abbreviation from MinguSeisakiGijutsuHozonkaiwas initiated to re-introduce a positive value that has been forgotten by people nowadays. This organization was established in 1973 focusing only on the preservation of rice straw culture, bamboo culture, and traditional weaving [7].

\subsection{Organization Structures}

Inagaki Wara no Kai has 12 members with organization structure consists of a president, vice president, accounting, secretary, public relations, quality control, and members. All the community members are coming from the local peoples around the Inagaki village. In the development process, each member in this community has a role in giving advice, therefore the characteristic of this organization is very fluid with kinship approaches not company management (relations similar with boss and subordinate) and bring strong connectivity between members.

In this organization, every member is carrying out their activities with passion, therefore it is no problem if they are not receiving a salary. Each member also has permanent works outside this organization, such as a high school teacher, government staff, farmers, and other works for their daily needs and also supporting the organizational operational costs. In terms of recruiting new members, after the workshop or events held by Inagaki Wara no Kai, a person who has an interest in rice straw culture is usually asking about how to join the organization, and straightly the organization members will follow up with registration process. In carrying out the organizational activities, the former school building was lent by the local government for free, the organization only bears the cost of building maintenance such as 
electricity and water. They are naming the building as Wa no Gakko (わの学校) or rice straw school.

While for other organization such as Warashibe has a more simple organizational structure: the leader of the workshop (a master of rice straw maker) and workshop maker. There are 50 members, but all of the members are the routine workshop members, not working with managerial responsibility. For Mingikai, the organization also has a simple structure, which consists of leader, accounting and members who routinely attend workshops and help leaders when performing workshops for the public. For the workshop location, this organization also supported by the government to utilize Japan Open-air Folk House Museum to fill the activities in the museum related to rice straw culture as a mutualism relationship between the organization and the museum. In supporting workshop leaders, the members of Mingikai are divided into three categories based on the experience, 1-year experience, 2 years of experience, and more than 2 years of experience.

\subsection{Organization Strategies}

There are 5 variables of organization strategies implemented by each rice straw organizations:

\subsubsection{Events and Crafts Development}

In Japan, rice straw culture is almost forgotten by local people, therefore it becomes interesting when rice straw organization re-introduce this culture. For the young generation, because it's a new thing for them, experiencing rice straw culture is an interesting activity, and for the elderly, this event is a nostalgic moment for reminding their old memories. To develop a sustainable events and appeal to the community, various strategies are applied by rice straw organizations. For developing their ideas, every organization is conducting a meeting to discuss an event implementation, budget, and event development routinely. For example, Inagaki Wara no Kai doing a routine meeting in the weekend twice in a month, while for the other rice straw organizations, the schedule is adjusted based on the free time of each member. Until present, every rice straw organization has routine programs for their activities each year.

In the development process, every organization is emphasizing either the history, meanings, values or production methods from the rice straw culture. Therefore, as the foundation for development, they researched to explore the diversity of rice straw culture and learned from the elderly how to create a proper rice straw craft. Inagaki Wara no Kai was conducting 5 years of research after the initial founding of the organization for understanding the rice straw craft in Aomori to be their foundation of development. Based on the development consideration, the development goals are to preserve the Japanese rice straw cultures through workshops, festivals, exhibitions, and product developments. It could be creating the traditional craft, developing a craft from the past, or creating a contemporary craft by utilizing the traditional production methods.

\section{a. Workshops}

Workshops are held internally and externally. The internal workshop is conducted to increase the skills of every organization's members, while an external workshop is performed for teaching public elements such as students, the local community, or visitors from outside the area. For example, in Mingikai, every week, members are trained to increase their hand skill levels from beating rice straw for preparation, until producing the crafts. In terms of external workshops, it will be performed based on the invitation. Inagaki Wara no Kai every year is creating workshops depends on the participants. They are usually offered a workshop 
of creating kakashi (scarecrow) dolls for children, small broom for adults, and shimenawa (rice straw rope for a ritual of purification) for a family workshop.

\section{b. Festival}

In the village, the festival could be carried on from generation to generation or developed based on historical backgrounds for celebrations. Inagaki Wara no Kai was developing a festival named Wara Uma (rice straw horse) to historically remember the role of horses for the community, especially in rice farming activities. In this festival, there were 20 rice straw horses (figure 4) created by the organization and paraded around the village. In this event, the local community was enjoying the festival, they were taking pictures and experiencing ride a rice straw horse. At night the rice straw horse was burned as a symbol of the community's sadness of the loss of the horse which in the past was considered as a part of the family.

\section{c. Contemporary Arts}

Utilizing the traditional methods of producing rice straw, development is also being made to create contemporary art. For example, a young member of Inagaki Wara no Kai developing a rice straw craft into a creation inspired by movies. He created a European dragon approach to give awareness of rice straw utilization culture through the shapes of a figure which is easily recognized by the young generation. Another object of contemporary art also created by the organization team such as a dome made by a rice straw production method calledwarabo or rice straw stick.

\section{d. Utility Craft Developments}

Internally, the development of rice straw craft is aimed to create alternative ideas for workshop (such as small tamagotsuto or egg packaging), a possibilities of a new product replacement based on rice straw (such as lamp cover, coaster, decorative elements and flower vase) and make crafts for merchandise (such as keychain and dolls). While the development of craft from external elements is usually based on scientific research. For example, the Ecofish development is a project collaboration between Inagaki Wara no Kai and Chiba University. Burned rice husk, based on the research is effectively purified the gray water[8]. Therefore, this project was conducted with Inagaki Wara no Kai in Junior High School in Tsugaru city to create a water filter with the shape of fish to create an attractive object for the students. After the workshop, the ecofishs were spread in irrigation channels and drainage around the school. This project effectively produced clean water for society and bring environmental awareness of the young generations in Inagaki.

\section{e. Exhibition}

One of the strategy for the rice straw organization to disseminate the rice straw crafts both traditional and modern are through exhibition. There are two alternative places for presenting an exhibition, inside the organization building or using government and private company facilities. Inside Wa no Gakko there is an exhibition place displaying the organization works, which public could see the collection based on the reservation for the visiting time. For the exhibition held outside the organization building, usually, the event is based on the invitation, such as Inagaki Wara no Kai was exhibiting their works in AEON mall Tsugaru, as a corporate social responsibility program for rice straw culture. Because this is a mutual relations program, therefore the exhibition space was given by the mall without any payment. 


\subsubsection{Economy}

The economy is one of the pillars of the project's sustainability. In rice straw organizations, the economical input is mainly for operational costs such as building maintenance (water and electricity), raw materials for workshop and development, accommodations, and other needs. To earn income for that, there are several schemes utilized by the organizations. The first revenue is from routine membership fees. Every member from rice straw organizations commonly has a main work, therefore, no problem for them to pay regular contributions. Usually, the contribution of money is routinely paid every month by the membersfor building maintenance, rice straw materials, working tools, internal celebrations, and cash reserve. On the other side, Mingikai using its members' fees only for purchasing rice straw materials because the payment for using the organization building is fully covered by the government. Besides routine revenue from the members, the rice straw organization receives non-routine income from workshops, selling rice straw crafts and sponsorships. Income from these activities is utilized for the same purposes as the routine income from the organization's members.

\subsubsection{Marketing}

In the beginning, the marketing method for disseminating the organizations' program was through connections at the office where the organization's members are working, for example offering the workshop to the local government or school. Through an approach to the local government, they could place their programs as one of the potential tourist locations inside the region by a pamphlet that accommodated by the government. Another marketing method used by all of the rice straw organizations is by creating the official website. The website could stand alone or become one with the institution such as Mingikai because they have a collaboration program with the Museum. Indirectly, the routine and non-routine activities carried out by the organization in the public spaces also indirectly make them famous locally. Moreover, after their activities were covered by the media such as television and newspaper, organizations are increasingly widely known by society.

\subsubsection{Rice straw materials management}

Rice straw is the key element for these organizations. This material is received from two sources, members who work as a farmer, and rice straw shops. To avoid the occurrence of fungus and make it durable for long term usage, before storing it in the storage room, rice straw is dried in the open-aired roof area. In Inagaki Wara no Kai, rice straw is gathered in September from farmers, and dried and stored in Wa no Gakko in October as preparation for one-year utilization.

\subsubsection{Event Implementation}

In presenting a workshop, several divisions have responsibilities that are interrelated to one another. A supervisor is a division who is the main "actor", a key person in the workshop, and works as the main teacher. A supervisor will be supported by members to effectively deliver the knowledge of making rice straw objects. For rice straw preparation, there is a division that works to make rice straw into tatakiwara or beaten rice straw. This preparation aims to shorten the workshop time and make it efficiently. In creating a craft for a festival and merchandise, there is a division that works as quality control. While the craft is produced, they will observe the work from a different angle to see the parts that need to be improved. Another division is providing tools when needed by the supervisor and team when working to avoid a disorganized situation. In the middle of working activities, a team also works preparing 
consumption, and at the end of the works, a team is responsible for cleaning the workspace. While working, all of the members are always using safety devices as a procedure, such as gloves, sleeve covers to prevent itching, and waist bags for tools such as scissors and ropes.

\section{CONCLUSION}

Local community are receiving a positive impact in terms of individual, social, and environment from the rice straw organizations' programs. These organizations operate sustainably because it leads by a person with high motivation in developing and preserving rice straw culture, and also supported by members with high interest in preserve and developing this culture. The rice straw organization approaches in Japan is very important to be a reference for another country that still considers rice straw as waste material. This approach is very possible to be implemented in country such as Indonesia, to raise people's awareness of the rice straw potencies. But in-depth research is needed first as a basis for developing rice straw, such as the essence of rice straw culture and its diversity in production methods.

\section{ACKNOWLEDGEMENT}

This research could not be done without the full support from Sumitomo Foundation which accommodates this research from start until finish through grant for Japan-related research project. We would like also to express our gratitude to all of the rice straw organizations that we have visited, Inagaki Wara no Kai, Warashibe, and Mingikai for their warm welcome and cooperativeness during the data collecting process.

\section{REFERENCES}

[1]. D. Wiyancoko. "Design Culture and Cultural Sustainability". Bulletin of Asian Design Culture Society, Issue no.5, pp.561-572, 2010.

[2]. K. Miyazaki. “Wara no Bunka(Rice Straw Culture). Hosei University Press. ISBN4-58832117-X, 1995.

[3]. A. Ueda, S. Ooga. "The Culture of Mottainai Seen as Symbiosis Between Japan's Ceramic-Producing Regions and the Natural Environment". Journal of JSSD (Japanese Society for the Science of Design), Vol.57, No. 1, pp.65-74, 2010

[4]. K. Miyazaki. "Presentation slides from Wara no Bunka.The third Meeting of Exchange, Akita Prefecture, Misato-cho Board of Education Lifelong Learning Division Historical Cultural Group, 2019.

[5]. Based on discussion with Inagaki Wara no Kai president and vice president, Inagaki Village, Aomori Prefecture, August 2019.

[6]. Based on discussion with Warashibe leaders, Yokohama city, August 2019.

[7]. Based on discussion with Mingikai leader, Kawasaki city, August 2019.

[8]. Y. Kondo, K. Nagase, T. Sato, K. Enari. "The Design of an Ecofish; A Handmade Graywater Purification Tool as a Circulation Type Resouce. The $49^{\text {th }}$ Annual Conference of JSSD Proceedings, page 72, 2003. 